\title{
Transfusion-free anesthetic management for open heart surgery in a neonate -A case report-
}

\author{
Jung Min Lee, Hyo-Jin Byon, Jin-Tae Kim, Hee-Soo Kim, and Chong Sung Kim \\ Department of Anesthesiology and Pain Medicine, Seoul National University Hospital, Seoul, Korea
}

In small infants or neonates, open heart surgery without transfusion can have many risks regarding inadequate oxygen delivery and coagulopathy. However, if parents refuse blood transfusion, cardiac surgery without transfusion should be considered. We report a case of bloodless cardiac surgery in a $2.89 \mathrm{~kg}$ neonate with Jehovah's Witness parents. Blood conserving strategies were used. Preoperatively, erythropoietin and iron were supplemented to increase the hemoglobin level. Intraoperatively, techniques for minimizing blood loss were used, such as reducing priming volume for cardiopulmonary bypass, a blood salvage system, and modified ultrafiltration. Postoperatively, pharmacologic agents were administered and blood sampling was minimized. (Korean J Anesthesiol 2010; 59: S141-S145)

Key Words: Bloodless cardiac surgery, Infant cardiac surgery, Jehovah's Witnesses.

Cardiopulmonary bypass (CPB) and cardiac surgery can cause bleeding and coagulopathy. In neonates, transfusion may be inevitable for open heart surgery because the $\mathrm{CPB}$ circuit surface and the priming volume are relatively large in relation to the patient size and blood volume. In addition, even a small blood loss can decrease the ability to deliver oxygen and cause coagulation abnormalities. Despite these facts, some Jehovah's Witnesses parents refuse transfusion to their children for religious reasons and this is a huge challenge for health care providers. We report a case of open heart surgery without transfusion in a $2.89 \mathrm{~kg}$ neonate whose parents are Jehovah's Witness.

\section{Case Report}

The patient was born by vaginal delivery at 39 weeks gestational age and weighed 2,870 g. The Apgar score was 6 at one minute and 9 at five minutes. Oxygen saturation $\left(\mathrm{SpO}_{2}\right)$ on $100 \%$ oxygen was $85 \%$ in the lower extremities, and $95 \%$ in the upper extremities. Prenatal examination showed: coarctation of the aorta, severe hydronephrosis (grade 5) with ureter dilatation in the right kidney, a single umbilical artery, periventricular echogenecity on brain ultrasound (grade 1), and cleft palate. Echocardiogram showed coarctation of the aorta with an isthmus of $2.7 \mathrm{~mm}$, a stenotic length of $6 \mathrm{~mm}$, patent ductus

Received: June 20, 2010. Revised: 1st, July 16, 2010; 2nd, July 27, 2010, 3rd, August 6, 2010. Accepted: August 19, 2010.

Corresponding author: Jin-Tae Kim, M.D., Ph.D., Department of Anesthesiology and Pain Medicine, Seoul National University Hospital, 101, Daehak-ro, Jongro-gu, Seoul 110-744, Korea. Tel: 82-2-2072-3295, Fax: 82-2-745-5587, E-mail: kimjintae73@dreamwiz.com

(c) This is an open-access article distributed under the terms of the Creative Commons Attribution Non-Commercial License (http:// creativecommons.org/licenses/by-nc/3.0/), which permits unrestricted non-commercial use, distribution, and reproduction in any medium, provided the original work is properly cited. 
arteriosus (PDA) of $3.3 \mathrm{~mm}$ with a bidirectional shunt (mainly left to right shunt), and an atrial septal defect (ASD). Heart CT showed the site of coarctation to be the upper thoracic aorta at the point of the insertion of the PDA.

Despite continuous intravenous infusion of prostaglandin E1 (PGE1) at $0.002 \mu \mathrm{g} / \mathrm{kg} / \mathrm{min}$, the PDA size was diminished and left ventricular dysfunction developed. Mechanical ventilation was started and PGE1, dobutamine, furosemide, spironolacton, and captopril were administered. After deciding for early surgical correction, treatment to increase hemoglobin was initiated because the parents refused transfusion to their child. Recombinant human erythropoietin (rHuEPO) $300 \mathrm{U} /$ $\mathrm{kg} /$ day was administered subcutaneously with ferric hydroxidepolymaltose complex solution $0.5 \mathrm{ml}$ (10 $\mathrm{mg} /$ day) per os for 10 days.

On the 16th day, blood pressures were $102 / 47 \mathrm{mmHg}$ in the right arm, 100/57 mmHg in the left arm, 59/39 $\mathrm{mmHg}$ in the right leg, and $60 / 27 \mathrm{mmHg}$ in the left leg. $\mathrm{SpO}_{2}$ on $20 \%$ oxygen was $92-100 \%$ in the upper extremities and $82-100 \%$ in the lower extremities. The heart rate was $136-154$ beats/min and

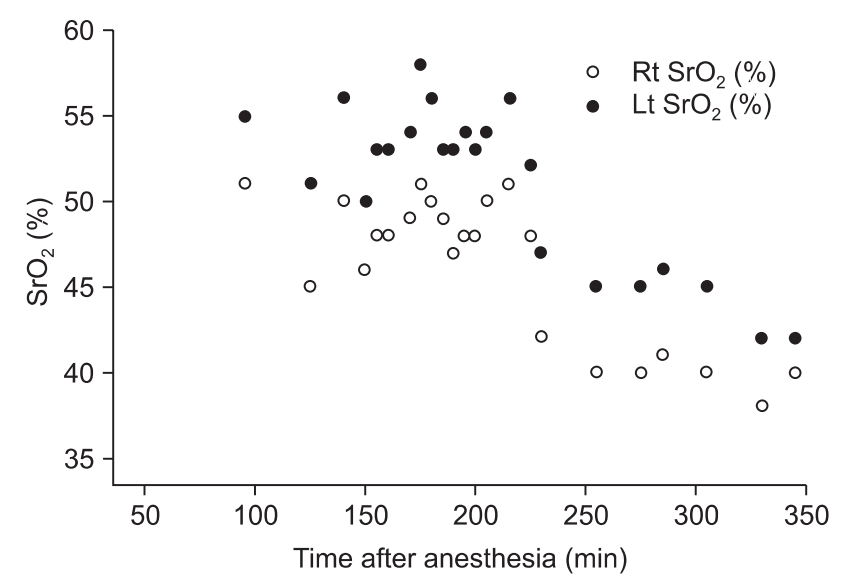

Fig. 1. Regional cerebral oxygen saturation. $145 \mathrm{~min}$ : CPB started, 185 min: regional cerebral perfusion started, $205 \mathrm{~min}$ : regional cerebral perfusion stopped, $235 \mathrm{~min}$ : mechanical ventilation started. the respiratory rate was $40-43$ breaths/min. The preoperative coagulation data was prothrombin time $75 \%$ (INR 1.21) and partial thromboplastin time 49.1 seconds. On the 17 th day, the patient (height $52 \mathrm{~cm}$, weight 2,890 g) received PDA division, coarctation repair and ASD closure. After induction with thiopental $15 \mathrm{mg}$, midazolam $0.3 \mathrm{mg}$, atropine $0.06 \mathrm{mg}$, and vecuronium $0.6 \mathrm{mg}$, anesthesia was maintained with a mixture of sufentanil $250 \mu \mathrm{g}$, midazolam $5 \mathrm{mg}$, and vecuronium $10 \mathrm{mg}$ in $100 \mathrm{ml}$ normal saline at $6 \mathrm{ml} / \mathrm{hr}$. Sevoflurane was administered at the discretion of the attending anesthesiologist. Arterial blood pressure was continuously measured in the left brachial artery and the left dorsalis pedis artery. Central venous pressure was monitored at the left subclavian vein. Cerebral oximeter probes were applied to monitor cerebral oxygen saturation.

After the patient was systemically heparinized by the intravenous injection of heparin $9 \mathrm{mg}$, CPB was started. At that time, the activated coagulation time (ACT) was 472 seconds. The neonate CPB system (Heart-Lung machine HL $30^{\mathrm{TM}}$, Maquet, Germany) was used with a high-performance, low prime volume oxygenator (RX-0 $5^{\mathrm{TM}}$, Terumo, Japan). Arterial and venous lines had a 3/16 inch inner diameter. With this setup, the bypass circuit was minimized in volume and primed with $50 \mathrm{ml}$ plasma solution A, $50 \mathrm{ml} 20 \%$ albumin, and $20 \mathrm{ml}$ hydroxyethyl starch. The total prime volume for the CPB was $120 \mathrm{ml}$. Cannulations were done in the right innominate artery, the right atrium, and the inferior vena cava, with 8 French, 14 French, and 14 French cannulae, respectively. During cannulation, $25 \mathrm{ml}$ hydroxyethyl starch and phenylephrine were administered. The pump flow was set at a rate of $1.84-2.47 \mathrm{ml} /$ $\min / \mathrm{m}^{2}$.

Regional cerebral perfusion using the right innominate artery was performed during the repair of the coarctation of the aorta. The left common carotid artery and left subclavian artery were snared down. The pump flow rate of regional cerebral perfusion was $150 \mathrm{ml} / \mathrm{min}$. For 20 minutes of regional cerebral perfusion, regional cerebral oxygen saturation ranged from $48 \%$ to $51 \%$ and $53 \%$ to $58 \%$ on the right and left sides, respectively (Fig. 1).

Table 1. Intraoperative Arterial Blood Gas Analysis (ABGA)

\begin{tabular}{|c|c|c|c|c|c|c|c|c|c|c|c|c|c|}
\hline & $\mathrm{FiO}_{2}$ & $\mathrm{pH}$ & $\begin{array}{c}\mathrm{pCO}_{2} \\
(\mathrm{mmHg})\end{array}$ & $\begin{array}{c}\mathrm{pO}_{2} \\
(\mathrm{mmHg})\end{array}$ & $\begin{array}{l}\text { Hct } \\
(\%)\end{array}$ & $\begin{array}{c}\mathrm{Na}^{+} \\
(\mathrm{mmol} / \mathrm{L})\end{array}$ & $\begin{array}{c}\mathrm{K}^{+} \\
(\mathrm{mmol} / \mathrm{L})\end{array}$ & $\begin{array}{c}\mathrm{HCO}_{3} \\
(\mathrm{mmol} / \mathrm{L})\end{array}$ & $\begin{array}{c}\mathrm{BE} \\
(\mathrm{mmol} / \mathrm{L})\end{array}$ & $\begin{array}{c}\mathrm{iCa} \\
(\mathrm{mmol} / \mathrm{L})\end{array}$ & $\begin{array}{l}\text { Glucose } \\
(\mathrm{mg} / \mathrm{dl})\end{array}$ & $\begin{array}{c}\text { Lactate } \\
(\mathrm{mmol} / \mathrm{L})\end{array}$ & $\begin{array}{c}\mathrm{SpO}_{2} \\
(\%)\end{array}$ \\
\hline Initial & 0.5 & 7.53 & 38 & 133 & 35 & 127 & 3.6 & 31.8 & 8.5 & 1.11 & 130 & 1.8 & 99 \\
\hline CPB \# 1 & - & 7.55 & 32 & 318 & 19 & 141 & 3.4 & 28.0 & 5.2 & 0.95 & 107 & 1.7 & 100 \\
\hline СРB \#2 & - & 7.39 & 49 & 277 & 22 & 144 & 2.6 & 29.7 & 4.3 & 1.00 & 107 & 1.8 & 100 \\
\hline СРВ \#3 & - & 7.49 & 38 & 300 & 19 & 138 & 3.7 & 29.0 & 5.2 & 1.16 & 119 & 3.1 & 100 \\
\hline $\mathrm{CPB} \# 4$ & - & 7.49 & 39 & 294 & 20 & 139 & 3.7 & 29.0 & 5.2 & 1.16 & 117 & 3.6 & 100 \\
\hline CPB off & 1.0 & 7.28 & 58 & 200 & 24 & 142 & 2.7 & 27.3 & 0.6 & 1.30 & 153 & 3.0 & 100 \\
\hline End of surgery & 0.7 & 7.38 & 47 & 194 & 22 & 145 & 2.7 & 27.8 & 2.7 & 1.18 & 152 & 3.3 & 100 \\
\hline
\end{tabular}

$\mathrm{FiO}_{2}$ : fraction of oxygenation, Hct: hematocrit, BE: base excess, iCa: ionized calcium, CPB: cardiopulmonary bypass, CPB \# 1: 7 minutes after CPB started, CPB \#2: 33 minutes after CPB started (7 minutes before regional perfusion), CPB \#3: 109 minutes after CPB started (48 minutes after regional perfusion), CPB \#4: 116 minutes after CPB started. 
Intraoperative arterial blood gas analysis (ABGA) was measured in regular intervals (Table 1). The intraoperative changes in lactate and $\mathrm{pH}$ were minimal. At the cardiopulmonary pump, calcium chloride $90 \mathrm{mg}$ was injected to correct the electrolyte imbalance. The total CPB time was 126 minutes. After weaning off the cardiopulmonary pump, modified ultrafltration was performed. Decannulation was then performed and the heparin activity was antagonized with protamine $9 \mathrm{mg}$ (ACT 415 seconds).

At the start of rewarming, sodium nitroprusside $0.5 \mu \mathrm{g} / \mathrm{kg} / \mathrm{min}$ was infused and dobutamine $5 \mu \mathrm{g} / \mathrm{kg} / \mathrm{min}$ was administered before weaning from the CPB. After weaning from the CPB, sodium nitroprusside was discontinued and the infusion rate of dobutamine was increased to $7 \mu \mathrm{g} / \mathrm{kg} / \mathrm{min}$, and the continuous infusion of epinephrine was started at $0.05 \mu \mathrm{g} / \mathrm{kg} / \mathrm{min}$ because of hemodynamic instability. Intermittently, a bolus of epinephrine and calcium chloride was injected for the control of blood pressure. Intraoperative hemodynamic changes and the nasopharyngeal temperature are shown in Fig. 2 and Fig. 3. After weaning from the $\mathrm{CPB}$, the cerebral oximeter values decreased and maintained relatively low levels despite a trial of increased cardiac output and maintenance of normocarbia.

At the end of surgery, autologous blood recovery systems (Cell Saver ${ }^{\mathrm{TM}}$, Medtronic, USA) were prepared to collect residual blood from the pump system. When $150 \mathrm{ml}$ blood was collected from the pump, the hematocrit value of collected blood was not checkable due to below $15 \%$. The collected blood from the pump was transfused for volume expansion. The patient was transferred to a neonatal intensive care unit with continuous intravenous infusion of dobutamine $5 \mu \mathrm{g} / \mathrm{kg} / \mathrm{min}$ and epinephrine $0.05 \mu \mathrm{g} / \mathrm{kg} / \mathrm{min}$. The total anesthetic time was 360 minutes and the total operative time was 240 minutes (CPB

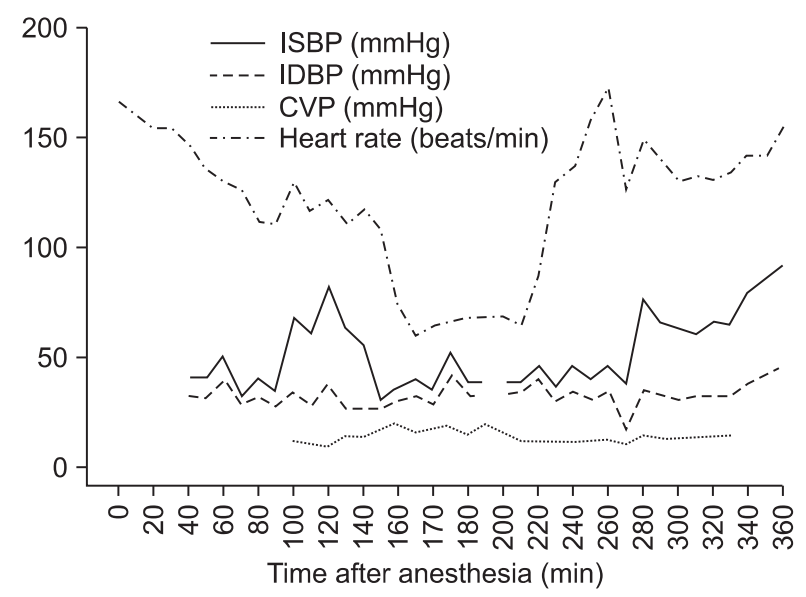

Fig. 2. Intraoperative hemodynamic changes. $145 \mathrm{~min}$ : CPB started, 185 min: regional perfusion started, $205 \mathrm{~min}$ : regional perfusion stopped, 235 min: mechanical ventilation started, 265 min: sodium ntroprusside infusion stopped, $310 \mathrm{~min}$ : epinephrine infusion started. time $126 \mathrm{~min}$ ). The total infused fluid was $15 \mathrm{ml}$ plasma solution A and $10 \mathrm{ml}$ Hartmann's solution. The estimated blood loss was about $30 \mathrm{ml}$ and the urine output was $30 \mathrm{ml}$.

Postoperatively, tranexamic acid $30 \mathrm{mg}$, divided into six doses, and vitamin K1 $0.6 \mathrm{mg}$ were supplemented on the day of surgery. Blood sampling was minimized. On postoperative echocardiogram, both left ventricular dysfunction and the site of coarctation of the aorta were improved. Ferric hydroxidepolymaltose complex and rHuEPO were intravenously administered for 9 days to correct postoperative anemia. Since leukocytosis and thrombocytosis occurred as a complication after the use of rHuEPO, only $50 \mathrm{mg}$ of ferric hydroxide-polymaltose complex was injected daily. The changes in hematologic data during the course of hospitalization are shown in Table 2. There was no further coagulation test to minimize blood sampling

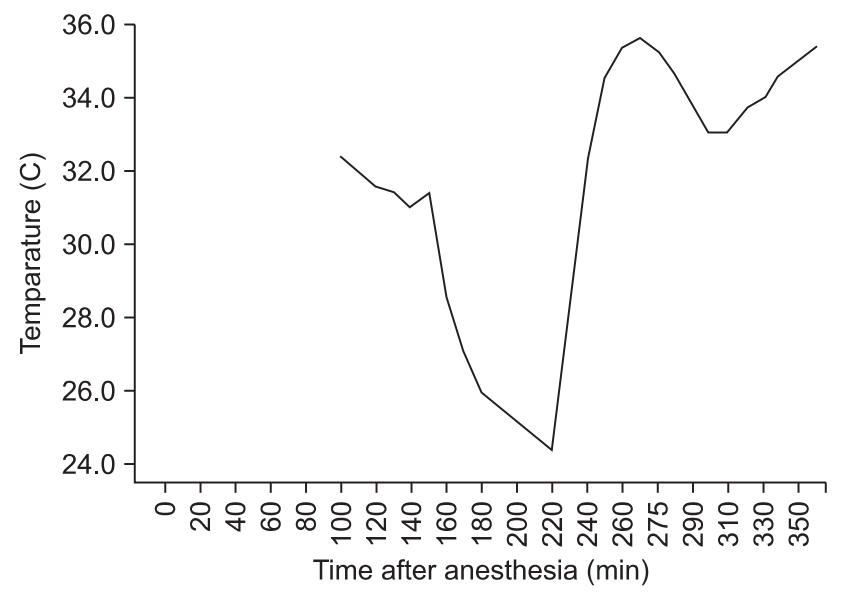

Fig. 3. Nasopharyngeal temperature changes. $145 \mathrm{~min}$ : CPB started, $185 \mathrm{~min}$ : regional perfusion started, $205 \mathrm{~min}$ : regional perfusion stopped, 220 min: rewarming started.

Table 2. Changes in Hematological Data

\begin{tabular}{lcccc}
\hline & $\begin{array}{c}\text { Hemoglohin } \\
(\mathrm{g} / \mathrm{dl})\end{array}$ & $\begin{array}{c}\text { Hematocrit } \\
(\%)\end{array}$ & $\begin{array}{c}\text { WBC } \\
\left(\times 10^{3} / \mu \mathrm{l}\right)\end{array}$ & $\begin{array}{c}\text { Platelet } \\
\left(\times 10^{3} / \mu \mathrm{l}\right)\end{array}$ \\
\hline Admission & 17.2 & 53.2 & 11.0 & 177 \\
Before surgery & 16.3 & 49.0 & $\mathrm{~N}$ & $\mathrm{~N}$ \\
End of surgery & 6.5 & 20.3 & 3.8 & 153 \\
POD \#1 & 7.8 & 23.0 & $\mathrm{~N}$ & $\mathrm{~N}$ \\
POD \#2 & 7.1 & 21.0 & $\mathrm{~N}$ & $\mathrm{~N}$ \\
POD \#3 & 6.5 & 19.0 & $\mathrm{~N}$ & $\mathrm{~N}$ \\
POD \#4 & 7.5 & 22.0 & $\mathrm{~N}$ & $\mathrm{~N}$ \\
POD \#5 & 7.1 & 21.0 & $\mathrm{~N}$ & $\mathrm{~N}$ \\
POD \#6 & 7.8 & 23.0 & $\mathrm{~N}$ & $\mathrm{~N}$ \\
POD \#7 & 7.1 & 21.0 & $\mathrm{~N}$ & $\mathrm{~N}$ \\
POD \#8 & 6.5 & 21.9 & 32.2 & 744 \\
POD \#10 & 6.4 & 21.6 & 26.5 & 463 \\
POD \#13 & 7.1 & 24.2 & 14.7 & 532 \\
POD \#26 & 7.1 & 24.1 & 5.8 & 576 \\
POD \#34 & 8.4 & 27.5 & 11.3 & 607 \\
\hline
\end{tabular}

POD: postoperative day, Patient was discharged on POD \#26, N: data not obtained. 
after surgery. On postoperative day 5 , the patient was extubated. There were no signs of bleeding and the vital signs were stable. On postoperative day 10 , the patient was transferred to a general ward without any complications. On postoperative day 7 , brain sonography showed no specific findings. However, on postoperative day 22, brain MRI showed diffusion restriction in the posterior side of the corpus callosal body and splenium, suggestive of acute to subacute infarction and diffuse brain atrophy. On neurological examination, there was no spasticity and no other specific findings except for hyperreflexia of both knees $(3+)$.

\section{Discussion}

In small infants or neonates, especially those under $5 \mathrm{~kg}$, open heart surgery without transfusion is considered a high risk procedure because of the high degree of hemodilution associated with impaired oxygen delivery and coagulopathy [1]. However, when the blood cannot be transfused, risk can be reduced by bloodless cardiac surgery techniques such as preoperative hematopoiesis enhancement, use of a downsized $\mathrm{CPB}$, intraoperative minimal blood loss, and postoperative bleeding control [2].

Preoperatively, the hemoglobin level can be increased with erythropoietin and oral iron supplementation. Erythropoietin therapy induces red blood cell volume expansion by increasing reticulocytes and its effectiveness can be evaluated by hemoglobin level. The optimal dose of erythropoietin is still unclear. However, for expanding red blood cell volume in a short period, a maximum dose of $600 \mathrm{IU} / \mathrm{kg}$ every second day is recommended. The supplementation of iron at at least 100 $\mathrm{mg} /$ day is important in erythropoietin therapy to stimulate bone marrow, especially in iron deficiency $[3,4]$. Furthermore, erythropoietin enhances cellular protection in hypoxic injuries and may limit myocardial injury and ventricular dysfunction after ischemic events [5,6].

Minimal intraoperative blood loss is important for transfusion-free cardiac surgery. Perioperative blood salvage can be performed by autologous blood recovery systems depending on the patient's wishes. A continuous column of blood must be maintained between the salvage device and the patient, which can salvage more than $60 \%$ of blood loss [7]. The modified ultrafiltration technique also removes major mediators of the inflammation response, decreases postoperative bleeding, and improves myocardial contractility and pulmonary compliance [1].

Open heart surgery using CPB impairs the function of the hemostatic system due to hemodilution, administration of heparin during $\mathrm{CPB}$, loss of platelets and impairment of platelet function, and inadequate functioning of the fibrinolytic system.
Since most Jehovah's Witness patients will not allow the use of fresh frozen plasma, platelet concentrate, or cryoprecipitate, pharmacologic aids may be useful in individual cases. For example, aprotinin, tranexamic acid, epsilon aminocaproic acid, desmopressin (deamino D-arginine vasopressin [DDAVP]), or recombinant factor VIIa can be supplemented. Aprotinin, derived from bovine lung, directly inhibits serine proteases, including plasmin, kallikrein and thrombin. It can improve platelet function and inhibit accelerated fibrinolysis during CPB. Lysine analogues, such as aminocaproic acid and tranexamic acid, are potent antifibrinolytic agents that interfere with the binding of plasminogen to fibrin. DDAVP, a vasopressin analogue, increases the plasma concentration of von Willebrand factor (and associated coagulation factor VIII) and thus improves primary hemostasis. These interventions improve clinical outcomes such as perioperative mortality and the need for rethoracotomy [8-11].

Body weight, preoperative hematocrit, priming volume of the $\mathrm{CPB}$ circuit, $\mathrm{CPB}$ time, and lowest hematocrit during $\mathrm{CPB}$ can predict requirements for blood transfusion during open heart surgery in small infants and neonates [12]. In our case, the patient was supplemented with erythropoietin and took oral iron prior to surgery. The effect of erythropoietin and oral iron supplementation seemed effective, preventing a further drop of the hematocrit level preoperatively. During surgery, the CPB circuit was modified to reduce total priming volume and the tubing length and diameter were minimized. Also, the modified ultrafiltration technique was applied. At the end of surgery, autologous blood recovery systems were prepared for collecting residual blood from the pump system.

During the CPB, hemodilution was performed to a hematocrit of $19 \%$. In addition, regional cerebral oxygen saturation maintained a low value after CPB. Cerebral autoregulation may be impaired after CPB. Alexi-Meskishvili et al. reported that hemodilution in cyanotic patients must be limited to less than $40 \%$ [1]. In the light of these facts, hypoxic injury due to a low hematorcrit may have caused the lesion which was seen on brain BRI on postoperative day 22. However, it is not yet clear whether the brain lesion is congenital or acquired. Further evaluation and follow-up will be required.

In our case, arterial blood pressure was monitored at the left brachial artery because cannulation of the arteries in the right arm failed. Therefore, it was not possible to monitor cerebral perfusion pressure during regional cerebral perfusion. A cerebral oximeter may have been helpful in this situation.

In previous cardiac surgery studies, the mortality and complication rates in Jehovah's Witness groups were similar to those of control groups, with Jehovah's Witness group having fewer hours of intubation, less blood loss over 24 hours, shorter intensive care unit length of stay and shorter total hospital 
stay [13-15]. In Korea, many surgeries proceed without blood transfusion for religious or medical reasons, but such procedures are rare in infants less than $3 \mathrm{~kg}$. Our patient is the smallest neonate in Korea to undergo transfusion-free open heart surgery.

In conclusion, we were able to perform transfusion-free open heart surgery in a neonate weighing less than $3 \mathrm{~kg}$ by increasing preoperative hemoglobin levels, reducing priming volume for $\mathrm{CPB}$, using the refined perfusion technique, minimizing perioperative blood loss with a blood salvage system, performing gentle surgery, and using pharmacologic agents.

\section{References}

1. Alexi-Meskishvili V, Stiller B, Koster A, Böttcher W, Hübler M, Photiadis J, et al. Correction of congenital heart defects in Jehovah's Witness children. Thorac Cardiovasc Surg 2004; 52: 141-6.

2. Lee JH, Shin DH, Hoo GJ, Lee CH, Na CY. Cardiac surgeries without transfusion. Korean J Anesthesiol 2007; 52: 530-6.

3. Goodnough LT, Skikne B, Brugnara C. Erythropoietin, iron, and erythropoiesis. Blood 2000; 96: 823-33.

4. Schälte G, Janz H, Busse J, Jovanovic V, Rossaint R, Kuhlen R. Lifethreatening postoperative blood loss in a Jehovah's Witness, treated with high-dose erythropoietin. Br J Anaesth 2005; 94: 442-4.

5. Cai Z, Manalo DJ, Wei G, Rodriguez ER, Fox-Talbot K, Lu H, et al. Hearts from rodents exposed to intermittent hypoxia or erythropoietin are protected against ischemia-reperfusion injury. Circulation 2003; 108: 79-85.

6. Cho SH, Koo BS, Kim SH, Chai WS, Jin HC, Kim YI. Experience of a bloodless operation and care for Jehovah's Witness - two case report -. Korean J Anesthesiol 2008; 55: 621-4.

7. Huët C, Salmi LR, Fergusson D, Koopman-van Gemert AW, Rubens F, Laupacis A. A meta-analysis of the effectiveness of cell salvage to minimize perioperative allogeneic blood transfusion in cardiac and orthopedic surgery. Anesth Analg 1999; 89: 861-9.

8. Levi M, Cromheecke ME, de Jonge E, Prins MH, de Mol BJ, Briët E, et al. Pharmacological strategies to decrease excessive blood loss in cardiac surgery: a meta-analysis of clinically relevant endpoints. Lancet 1999; 354: 1940-7.

9. Schouten ES, van de Pol AC, Schouten AN, Turner NM, Jansen NJ, Bollen CW. The effect of aprotinin, tranexamic acid, and aminocaproic acid on blood loss and use of blood products in major pediatric surgery: a meta-analysis. Pediatr Crit Care Med 2009; 10: 182-90.

10. Guay J, de Moerloose P, Lasne D. Minimizing perioperative blood loss and transfusions in children. Can J Anaesth 2006; 53: S59-67.

11. Eaton MP. Antifibrinolytic therapy in surgery for congenital heart disease. Anesth Analg 2008; 106: 1087-100.

12. Kotani Y, Honjo O, Nakakura M, Fujii Y, Ugaki S, Oshima Y, et al. Single center experience with a low volume priming cardiopulmonary bypass circuit for preventing blood transfusion in infants and small children. ASAIO J 2009; 55: 296-9.

13. Reyes G, Nuche JM, Sarraj A, Cobiella J, Orts M, Martin G, et al. Bloodless cardiac surgery in Jehovah's witnesses: outcomes compared with a control group. Rev Esp Cardiol 2007; 60: 727-31.

14. Spence RK, Carson JA, Poses R, McCoy S, Pello M, Alexander J, et al. Elective surgery without transfusion: influence of preoperative hemoglobin level and blood loss on mortality. Am J Surg 1990; 159: $320-4$.

15. Putney LJ. Bloodless cardiac surgery: not just possible, but preferable. Crit Care Nurs Q 2007; 30: 263-70. 